the Dumbarton Oaks document--the much fuller elaboration of the scope and functions of the Economic and Social Council. Dismissed rather perfunctorily in Chapter 9 of the Dumbarton Oaks proposals, this scheme has now been developed at length in Chapters 9 and 10 of the new Charter embracing Articles 55-72. The Economic and Social Council, which will consist of eighteen members, is now named as one of the principal organs of the United Nations, and its duties will include that of initiating research and of recommending action to the Assembly on all international economic and social questions, including health.

This is not the place for a detailed examination of the nineteen chapters and 111 articles to which the Charter now runs, but the importance of the document cannot be over-emphasized. It represents first, as already noted, the cardinal and central fact that it is the duty of the powerful nations to assume the responsibility of leadership towards a world of peace, though it should not be forgotten that restraint will also be demanded of the smaller countries in the Economic and Social Council and in the Assembly if dissensions are not to arise. Next, the Charter represents a reasonable attempt to utilize available experience, both of regional bodies and of functional organizations. As President Truman rightly said, it shows that the lessons of military and economic co-operation during the War have been learnt, and that the pooling of experience and resources in the work of the Combined Raw Materials Board, the Food Board and the Combined Chief of Staffs Committee is to be turned to our advantage for the pur. poses of peace and not rashly jettisoned as in 1919 .

But despite the embodiment of such methods and experience in the new Charter, and its close relation to the policies and organization already represented by the United Nations Relief and Rehabilitation Administration, the Food and Agricultural Organization, the monetary Conference at Bretton Woods, and the aviation conference at Chicago, the kernel of the new organization is the Security Council ; and, like the League of Nations, the United Nations will ultimately stand or fall by the success or failure of its machinery for the maintenance of peace.

The Charter itself is nothing if it fails to hold the loyalty of the major Powers, who alone can give it body and life. Already it is clear that the leaders of Great Britain, the United States, and the U.S.S.R. are ready to assume the responsibility of leadership towards a world of peace. In addition, we require indeed an effective agency for constant and thorough interchange of thought and ideas, through which alone can come a better and more tolerant understanding among nations and among peoples. An enduring peace involves a victory in the minds of men over the evil ideas and passions that have divided mankind and plunged the world into chaos. It involves the formation of a world opinion which clearly understands the price that has to be paid for peace, the restraints which must be accepted as the alternative to anarchy-the limitations as well as the opportunities of world organization. The creation of that opinion is a matter of education in which there is a place for every man and woman of good will.

\section{R.A.F. AERIAL SURVEY IN PEACE-TIME}

$\mathrm{T}$ HE necessities of war have brought about the development of photographic reconnaissance upon a scale previously unapproached, and at a technical and administrative level of great competence. To achieve this the Royal Air Force has built upon the pioneer experience of the War of 1914-18, on Services and commercial experience between the Wars, and on the scientific knowledge of many types of imported specialists in fields related to aerial survey, such, for example, as archæologists, geographers and ecologists.

Now that a stage of hostilities has been reached. when peace-time organization deserves attention, it is appropriate to recognize that in this branch of R.A.F. activities there exist material and experience of great potential value for those years of post-war development which lie ahead, and during which Great Britain cannot afford to neglect any prospective means of scientific and technical advancement.

These considerations are prompted by a memorandum circulated by the British Ecological Society to scientific authorities and responsible government departments, and headed "Memorandum on the Establishment of an Aerial Unit for Scientific Work". Ecology, which has been defined as "scientific natural history", has brought modern techniques of science to bear upon the complex phenomena of plant and animal life in relation to its natural environment. Its workers have constantly concerned themselves with problems of relationships between vegetation, animal life, topography and soil. Their outlook has progressively established itself as fundamental to the disciplines of forestry, agriculture, geography and archæology. It is suitable therefore that ecologists should raise this issue; but it must be apparent that even wider fields than those they mention can be served by the widespread use of aerial mapping.

Photographic aerial survey has immense advantages over ground mapping : apart from the speed with which maps can be constructed from an air survey, air photography records automatically a multitude of distributional features of vegetational, geological, archæological and economic interest, and these remain available for inspection and analysis in the photographic prints. The aerial photographer, even when mapping without specific aim, cannot help but record an infinity of useful facts, of which he remains unaware, but which deliberate ground mapping could either not yield at all or yield only with immense labour. The value of this speedy, accurate and comprehensive mapping is too apparent to need stressing. It immediately affects geography, engineering, economics, and regional and town planning, especially perhaps in areas of great extent, complexity, or inaccessibility. It is, however, to its great potentialities in less obvious directions that our attention is now specially directed.

Archæologists were from the first keenly aware of the potential value to them of the point of view given 
by the aeroplane, and many new and important sites have been disclosed by its aid. Thus air photography lod to the excavation of Woodhenge in Wiltshire, and its counterpart at Arminghall in Norfolk, and disclosed the Romano-British system of field boundaries in relation with the prehistoric river systems of the East Anglian fens. Readers will indeed already be familiar with such achievements through the publications of Mr. O. G. S. Crawford on the subject, and-through the admirable pioneer investigations of Wing Commander Insall.

Foresters have seized the opportunities of aerial survey no less readily. Dr. Dudley Stamp in 1925 published results of an aerial survey of Burmese forests in the Irrawaddy Delta; Dr. Bourne, of the Imperial Forestry Institute, in 1930, indicated its immense potentialities in regional survey, illustrating his thesis by the aerial survey of tracts of southern England; Dr. B. Lindquist of Lund was able, by air survey at a season when the beech foliage contrasted with that of other trees, to complete a survey of the beech forests throughout southern Sweden; and more recently foresters in Canada and the United States have mapped and classified immense areas of forest land, and from the air photographs have derived information not only of vegetation types, tree species, and tree density, but also details of composition, age, and structure of the most direct importance to forest management. Other vegetation surveyed from the air includes types so divergent as prairie, sphagnum bog, coastal eliffs and submerged seaweed beds. Very often the changes such types show are intimately associated with topographic processes of great importance, such as those of soil erosion and coastal modification. The study of aerial plankton, the wind's freight of dust, pollen, bacteria, fungus spores and aphids, the rapid detection and report of the movements of big game or of locust swarms, the control of pests by spraying or dusting from the air, are yet other instances which indicate the wide scope of further application of the aeroplane to the service of biological science.

With the proved value of these applications in mind, and supported by an informative schedule of provisional schemes of investigation, the British Ecological Society suggests that after the War there should be established a permanent R.A.F. unit the services of which should be available for scientific work, not necessarily limited to photographic survey though chiefly concerned therein. To the arguments which are offered of the scientific potentialities of air survey thus fostered we would add that the effect upon the service unit of constant contact with men of science of varied kinds, and of attempts jointly with them to solve scientific problems of diverse character, must have the effect of keeping outlook and methods flexible and modern. Moreover, just as in war-time photographic survey has drawn extensively upon the services of academic men of science to help in such problems as the evaluation of cover, penetrability, and similar qualities of unfamiliar vegetation, so it remains desirable from the service point of view to keep and strengthen the links already made with such men of science.
The air photographs already obtained by the R.A.F. are of immense value to Britain, and the memorandum rightly recommends the establishment of a central library of air photographs available for scientific use. There should be destruction of negatives and prints of aerial photographs only where national security clearly demands it : the normal course should be for all good-quality negatives to go to the central library for indexing, and flights for training in air photography could with advantage regularly be made over targets selected for scientific usefulness.

We have mentioned but a fraction of the scientific issues touched by the new proposal, but it is clearly one which must receive warm support from men of science in all parts of the Commonwealth. If suitable administrative machinery can be devised, it should become a tool of great usefulness, helping men of science to maintain in the peace the quality of service they have so conspicuously upheld throughout the War.

\section{GENETICS AND MAJOR EVOLUTIONARY CHANGE}

Tempo and Mode in Evolution

By George Gaylord Simpson. (Columbia Biological Series, No. 15.) Pp. xviii +237. (New York: Columbia University Press ; London : Oxford University Press, 1944.) 23s. 6d. net.

TN "Tempo and Mode in Evolution" G. G. Simpson 1 has done for palæontology what Ernst Mayr, in his "Systematics and the Origin of Species", did for taxonomy-he has reviewed the facts of his special branch of biology in the light of modern genetics. The result is an interesting and significant contribution to the synthesis now occurring in the general field of evolution.

Palæontology had indeed tended to build up its own set of evolutionary concepts, such as orthogenesis, racial senility, evolutionary momentum, and the like, between which and the concepts of neo-mendelism there seemed to be little or no possible connexion. Dr. Simpson has performed the double task of reminding neo-zoologists of many facts of palæontology which they have tended to overlook as unfamiliar or inconvenient, and at the same time showing the possibility of accounting for them in genetic terms.

The most familiar phenomenon brought to light by palæontology is the existence of evolutionary trends, as in the horses, the titanotheres, and almost every group of which there is abundant fossil record. The term orthogenesis has been applied to these sometimes as a description, sometimes as an explanation. Dr. Simpson reminds us that in point of fact these trends, though often broadly directional, are rarely rectilinear for more than short periods, that they may change in rate, that they may be reversed, that they show much branching (the horse stock has at least twelve branches of generic rank, besides the conventionally 'main' line leading to Equus). The facts are "flatly inconsistent with the idea of any inherent rectilinearity, predetermined trend, or solely preadaptive control". They can, however, be ex. 